\title{
A Dysfunctional Movement Protein of Tobacco mosaic virus Interferes with Targeting of Wild-Type Movement Protein to Microtubules
}

\author{
Guy Kotlizky, ${ }^{1}$ Aviva Katz, ${ }^{1}$ Jessica van der Laak, ${ }^{2}$ Vitaly Boyko, ${ }^{2}$ Moshe Lapidot, ${ }^{3}$ \\ Roger N. Beachy, ${ }^{4}$ Manfred Heinlein, ${ }^{2}$ and Bernard L. Epel ${ }^{1}$ \\ ${ }^{1}$ Department of Plant Sciences, Faculty of Life Sciences, Tel Aviv University, Tel Aviv 69978, Israel; \\ ${ }^{2}$ Friedrich Miescher Institut, Maulbeerstrasse 66, CH-4058 Basel, Switzerland; ${ }^{3}$ Department of Virology, \\ The Volcani Center, Box 6, Bet Degan 50250, Israel; ' ${ }^{4}$ onald Danforth Plant Science Center, 7425 \\ Forsyth Boulevard, Box 1098, St. Louis, MO 63130, U.S.A. \\ Submitted 17 November 2000; Accepted 27 March 2001.
}

The Tobacco mosaic virus (TMV) movement protein $\left(\mathrm{MP}^{\mathrm{TMV}}\right)$ mediates cell-to-cell viral trafficking by altering properties of the plasmodesmata $(P d)$ in infected cells. During the infection cycle, MP $^{\mathrm{TMV}}$ becomes transiently associated with endomembranes, microfilaments, and microtubules (MT). It has been shown that the cell-to-cell spread of TMV is reduced in plants expressing the dysfunctional MP mutant MP ${ }^{\mathrm{NT}-1}$. To expand our understanding of the MP function, we analyzed events occurring during the intracellular and intercellular targeting of MP ${ }^{\mathrm{TMV}}$ and MP ${ }^{\mathrm{NT}-1}$ when expressed as a fusion protein to green fluorescent protein (GFP), either by biolistic bombardment in a viral-free system or from a recombinant virus. The accumulation of $\mathrm{MP}^{\mathrm{TMV}}$ :GFP, when expressed in a viral-free system, is similar to $\mathrm{MP}^{\mathrm{TMV}}$ :GFP in TMVinfected tissues. Pd localization and cell-to-cell spread are late events, occurring only after accumulation of MP:GFP in aggregate bodies and on MT in the target cell.

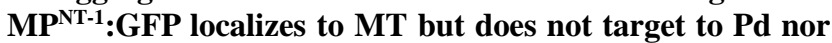
does it move cell to cell. The spread of transiently expressed $M P^{\mathrm{TMV}}$ :GFP in leaves of transgenic plants that produce $M P^{\mathrm{NT}-1}$ is reduced, and targeting of the $M^{T M V}$ :GFP to the cytoskeleton is inhibited. Although $M^{T M V}$ :GFP targets to the Pd in these plants, it is partially impaired for movement. It has been suggested that MP ${ }^{\mathrm{NT}-1}$ interferes with host-dependent processes that occur during the intracellular targeting program that makes MP movement competent.

Additional keywords: intercellular trafficking, intracellular trafficking.

Plant viruses spread from cell to cell by exploiting plasmodesmata $(\mathrm{Pd})$, coaxial membranous tunnels that span cell walls and interconnect the cytoplasm of adjacent cells. The cell-to-cell spread of a plant virus requires one or more virusencoded proteins, termed "movement proteins" (MPs). The

Corresponding author: B. L. Epel; Telephone: +972 36408598 ; Fax: +972 3640 9380; E-mail:blepel@post.tau.ac.il identification of a virus-encoded MP was first made for Tobacco mosaic virus (TMV) (Deom et al. 1987; Meshi et al. 1987). MPs potentiate virus movement by altering Pd properties in infected tissues (Atabekov and Taliansky 1990; Hull 1989; Lazarowitz and Beachy 1999).

Studies with different taxonomic classes of viruses indicate that there are at least two distinct mechanisms for the cell-tocell spread of infection. One mechanism, exemplified by TMV, involves a virus-encoded MP that facilitates the passage of a nonvirion form of the virus. The second mechanism, exemplified by Cowpea mosaic virus, involves the movement of the complete virus particle within tubular structures through modified Pd (Van Lent et al. 1990).

Extensive research over the past 10 years to elucidate the interactions between the TMV movement protein $\left(\mathrm{MP}^{\mathrm{TMV}}\right)$ and host components has provided a partial image of mechanisms of the cell-to-cell spread of infections. MP ${ }^{\mathrm{TMV}}$ and $\mathrm{MP}^{\mathrm{TMV}}$ fused with green fluorescent protein $\left(\mathrm{MP}^{\mathrm{TMV}}: \mathrm{GFP}\right)$, localize to the Pd (Atkins et al. 1991; Ding et al. 1992; Epel et al. 1996; Heinlein et al. 1995; Moore et al. 1992; Oparka et al. 1997), components of the cell cytoskeleton (Heinlein et al. 1995; McLean et al. 1995), and endoplasmic reticulum (ER) membranes (Heinlein et al. 1998; Reichel and Beachy 1998). Although recombinant MP ${ }^{\mathrm{TMV}}$ coupled to fluorescent dyes spreads cell to cell (Waigmann et al. 1994), when microinjected into tobacco mesophyll cells, $\mathrm{MP}^{\mathrm{TMV}}$ :GFP fusion protein expressed as a result of $\mathrm{TMV}\left(\mathrm{MP}^{\mathrm{TMV}}\right.$ :GFP) infection, exhibited a complex targeting profile and very different kinetics of cell-to-cell movement compared with microinjected MP (Boyko et al. 2000a; Epel et al. 1996; Heinlein et al. 1995; Heinlein et al. 1998; Oparka et al.1997; Szesci et al. 1999).

The spread of wild-type TMV is reduced in transgenic plants expressing the mutant MP, MP ${ }^{\mathrm{NT}-1}$ (Cooper et al. 1995; Lapidot et al. 1993). This finding suggests that the presence of the mutant MP somehow interferes with the normal activity of the wild-type MP. The mechanism of interference of viral spread is unclear and could provide an important tool in analyzing normal MP activity.

In order to expand our understanding of the MP function, we analyzed and compared events that occur during the intra- 
cellular and intercellular targeting of $\mathrm{MP}^{\mathrm{TMV}}$ :GFP and of $\mathrm{MP}^{\mathrm{NT}-1}$ :GFP fusion proteins in leaves of host and nonhosts as well as in leaves of wild-type Nicotiana benthamiana, transgenic $N$. benthamiana expressing $\mathrm{MP}^{\mathrm{NT}-1}$, and in BY-2 protoplasts. By following the dynamics of the accumulation of the transiently expressed GFP-labeled proteins, we elucidated steps in the intracellular and intercellular targeting of MP and addressed how $\mathrm{MP}^{\mathrm{NT}-1}$ provides resistance to TMV spread.

\section{RESULTS}

\section{Transient expression of $\mathrm{MP}^{\mathrm{TMV}}$ :GFP in epidermal cells of $N$. benthamiana and cucumber.}

During a viral infection of leaves or BY-2 protoplasts, $\mathrm{MP}^{\mathrm{TMV}}$ :GFP targets to the ER and cytoskeleton elements, whereas in leaves it also targets to Pd (Epel et al. 1996; Heinlein et al. 1995; Heinlein et al. 1998; Mas and Beachy 1999; McLean et al. 1995; Reichel and Beachy 1998). To follow MP ${ }^{\mathrm{TMV}}$ targeting and cell-to-cell movement in the absence of viral infection, we employed particle bombardment of plasmid DNA ( $p 35 S$-mp:gfp) encoding MP ${ }^{\mathrm{TMV}}$ :GFP expressed from the cauliflower mosaic virus (CaMV) $35 \mathrm{~S}$ promoter.

Experiments were performed with leaves of $N$. benthamiana and cotyledons of cucumber (Cucumis sativa) and tomato (Lycopersicon esculentum) (data not shown). N. benthamiana and $L$. esculentum are systemic hosts for TMV, whereas the inoculation of cucumber results in pinpoint chlorotic lesions. On cucumber cotyledons, no virus spread was observed beyond the chlorotic lesions (data not shown).
Following the bombardment of near fully expanded leaves of $N$. benthamiana or cotyledons of cucumber with $p 35 S$ $m p: g f p$, protein expression was determined in epidermal cells by fluorescence microscopy at $10,24,48$, and $72 \mathrm{~h}$ postbombardment (hpb). All plants exhibited similar results. At 24 $\mathrm{hpb}$, fluorescence was observed in fluorescent bands that traversed cell walls (Fig. 1), which are presumed to be Pd (Oparka et al. 1997). There also was weak fluorescence from within the cell, but no nuclear localization was observed (Fig. 1A and B). More than $50 \%$ of the sites contained multiple cells, presumably as a result of the spread of MP ${ }^{\mathrm{TMV}}$ :GFP from the initially transfected cell to adjoining cells. At $48 \mathrm{hpb}$, more than $90 \%$ of the fluorescent sites on $N$. benthamiana encompassed an average of five fluorescent cells (Fig. 2A). Similar observations were made at $72 \mathrm{hpb}$, with no increase in the number of fluorescent cells per site. Stomatal guard cells trapped within the patches of fluorescent cells did not display cytoplasmic- or wall-associated fluorescence, probably as a result of the absence of plasmodesma bridges between these cells and adjacent cells. Similar results were obtained with $L$. esculentum (not shown). In control experiments in which fully expanded leaves of $N$. benthamiana or cotyledons of cucumber were bombarded with $p 35 S$ - $g f p$, no cell-to-cell movement of GFP was detected (Fig. 1C and D).

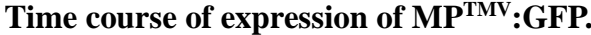

In order to follow the targeting time course of MP ${ }^{\mathrm{TMV}}$ :GFP to the various subcellular structures, we observed 30 individual cells over time. Figure $3 \mathrm{~A}$ to $\mathrm{C}$ shows an epidermal cell in a fully expanded leaf of $N$. benthamiana bombarded with the
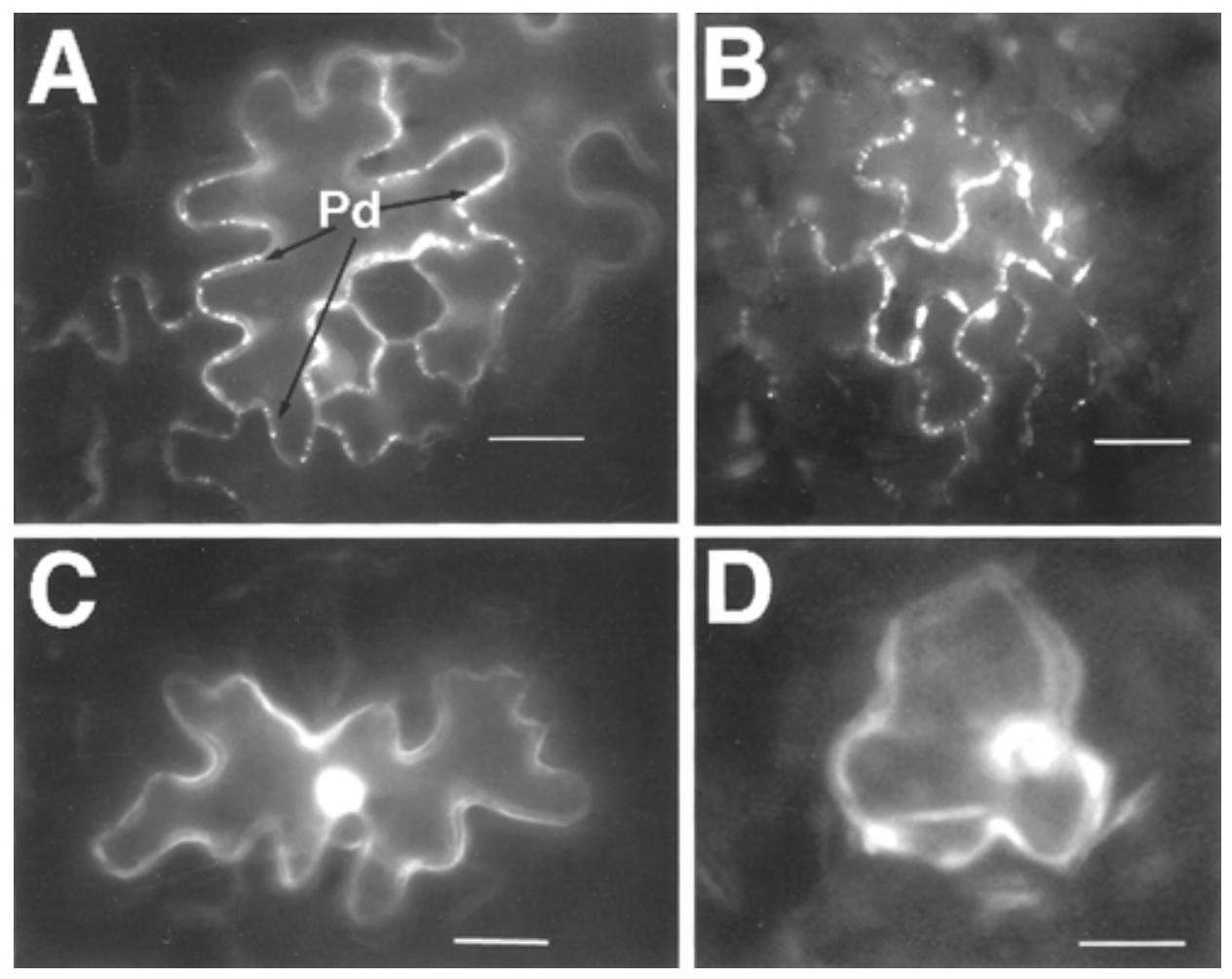

Fig. 1. Fluorescence micrograph of epidermal cells of $\mathbf{A}$ and C, Nicotiana benthamiana source leaf and $\mathbf{B}$ and $\mathbf{D}$, cucumber cotyledon photographed 48 $\mathrm{h}$ postbombardment of leaf with $p 35 S-m p: g f p$ (A and B) or p35-gfp (C and D). Free green fluorescent protein (GFP) did not move from cell to cell, whereas $\mathrm{MP}^{\mathrm{TMV}}$ :GFP did move cell to cell and accumulated in transwall structures (presumptively plasmodesmata). Micrograph bars $=10 \mu \mathrm{m}$. 
p35S-mp:gfp plasmid and photographed at 6, 12, and $24 \mathrm{hpb}$. At $6 \mathrm{hpb}$, when fluorescence was first detected, most of the $\mathrm{MP}^{\mathrm{TMV}}$ :GFP was associated with particulate bodies in the interior of the cell and with cytoskeletal elements. The bodies containing MP:GFP appeared to accumulate on the cytoskeleton (Fig. 3D). At this time point, very little fluorescence was detected near the cell wall region or in transwall structures (presumptive Pd) and no cell-to-cell movement was detected. When cells were examined at $12 \mathrm{hpb}$, some changes in the spatial orientation of the signal were detected and MP ${ }^{\mathrm{TMV}}$ :GFP was detected on very thin strands, presumably microtubules (MT) (Fig. 3B), and with aggregate bodies in the cortical region of the cell that is closely associated with the cell wall and plasma membrane. At this time point, MP localizes to transwall structures (presumptive Pd). Cell-to-cell spread, however, generally is not detected. By $24 \mathrm{hpb}$, the cytoplasmic fluorescent bodies had completely disappeared and no association of $\mathrm{MP}^{\mathrm{TMV}}$ :GFP with MT was detected. By this time point, $\mathrm{MP}^{\mathrm{TMV}}$ :GFP was localized only to transwall structures (presumptive Pd), and had moved to adjacent cells (Fig. 3C). Cell-to-cell spread was rapid, and we did not detect an association of $\mathrm{MP}^{\mathrm{TMV}}$ :GFP with cortical bodies or cytoskeleton elements. Approximately $80 \%$ of the cells observed followed this scenario. In $20 \%$ of the cells, this scenario was accelerated and the transition of $\mathrm{MP}^{\mathrm{TMV}}$ :GFP from the interior of the cell to the wall and cell-to-cell movement takes place within the first $12 \mathrm{~h}$ (data not shown).

\section{Expression of MP ${ }^{\mathrm{TMV}}$ :GFP in subliminal hosts.}

To date, it is not clear what determines host-virus compatibility. In some plants such as cotton and cowpea, TMV is capable of replication but the virus does not spread cell to cell (Sulzinski and Zaitlin 1982). To observe the accumulation of $\mathrm{MP}^{\mathrm{TMV}}$ in these subliminal hosts, cotyledons of cotton and bifoliate leaves of cowpea tissue were bombarded with $p 35 S$ $m p: g f p$ or with $p 35 S-g f p$. Free GFP localized in much the same way as subcellular sites in $N$. benthamiana cells, including the cell cytoplasm and nucleus. It did not localize to the Pd or move from cell to cell (Fig. 4A and data not shown).

In cowpea, $\mathrm{MP}^{\mathrm{TMV}}$ :GFP targeted to transwall sites (presumptive Pd) (Fig. 4B), but cell-to-cell movement was observed only in $30 \%$ of the 28 fluorescent sites examined. In cases where $\mathrm{MP}^{\mathrm{TMV}}$ :GFP moved cell to cell, it spread only to a single adjacent cell. In sites where no cell-to-cell movement was detected, $\mathrm{MP}^{\mathrm{TMV}}$ :GFP was associated with putative $\mathrm{Pd}$ sites. Apparently, such association is not sufficient for spread. In cotton, $\mathrm{MP}^{\mathrm{TMV}}$ :GFP exhibited no cell-to-cell movement $(0$ out of 28 cells observed) and no Pd localization was observed. The $\mathrm{MP}^{\mathrm{TMV}}$ :GFP fusion protein accumulated along the cell wall and may have become associated with the cell membrane (data not shown). It thus appears that $\mathrm{MP}^{\mathrm{TMV}}$ :GFP is incapable of targeting to $\mathrm{Pd}$ in cotton cotyledons.

\section{Expression of the dysfunctional MPNT-1 fused to GFP.}

The MP ${ }^{\mathrm{NT}-1}$ mutant of TMV MP contains a three-aminoacid deletion near the $\mathrm{N}$ terminus (amino acids 3 to 5) and does not support cell-to-cell movement of virus infection (Boyko et al. 2000b; Gafny et al. 1992; Lapidot et al. 1993). When $\mathrm{MP}^{\mathrm{NT}-1}$ :GFP was expressed via bombardment of $N$. benthamiana leaves with plasmid p35S-nt-1:gfp, neither localization to Pd nor cell-to-cell movement was observed (Fig. 5). The initial stages of $\mathrm{MP}^{\mathrm{NT}-1}$ GFP targeting are similar to that of $\mathrm{MP}^{\mathrm{TMV}}$ :GFP. The fluorescent bodies that form 10 to $12 \mathrm{hpb}$, however, are fewer in number and smaller in size (Fig 5A) than those produced following bombardment with $p 35 S$ $m p: g f p$ (Fig 3B). Although the fluorescent bodies dissipate by $24 \mathrm{hpb}$, as in the case of $\mathrm{MP}^{\mathrm{TMV}}: \mathrm{GFP}, \mathrm{MP}^{\mathrm{NT}-1}$ :GFP remains associated with filamentous structures and does not accumu-

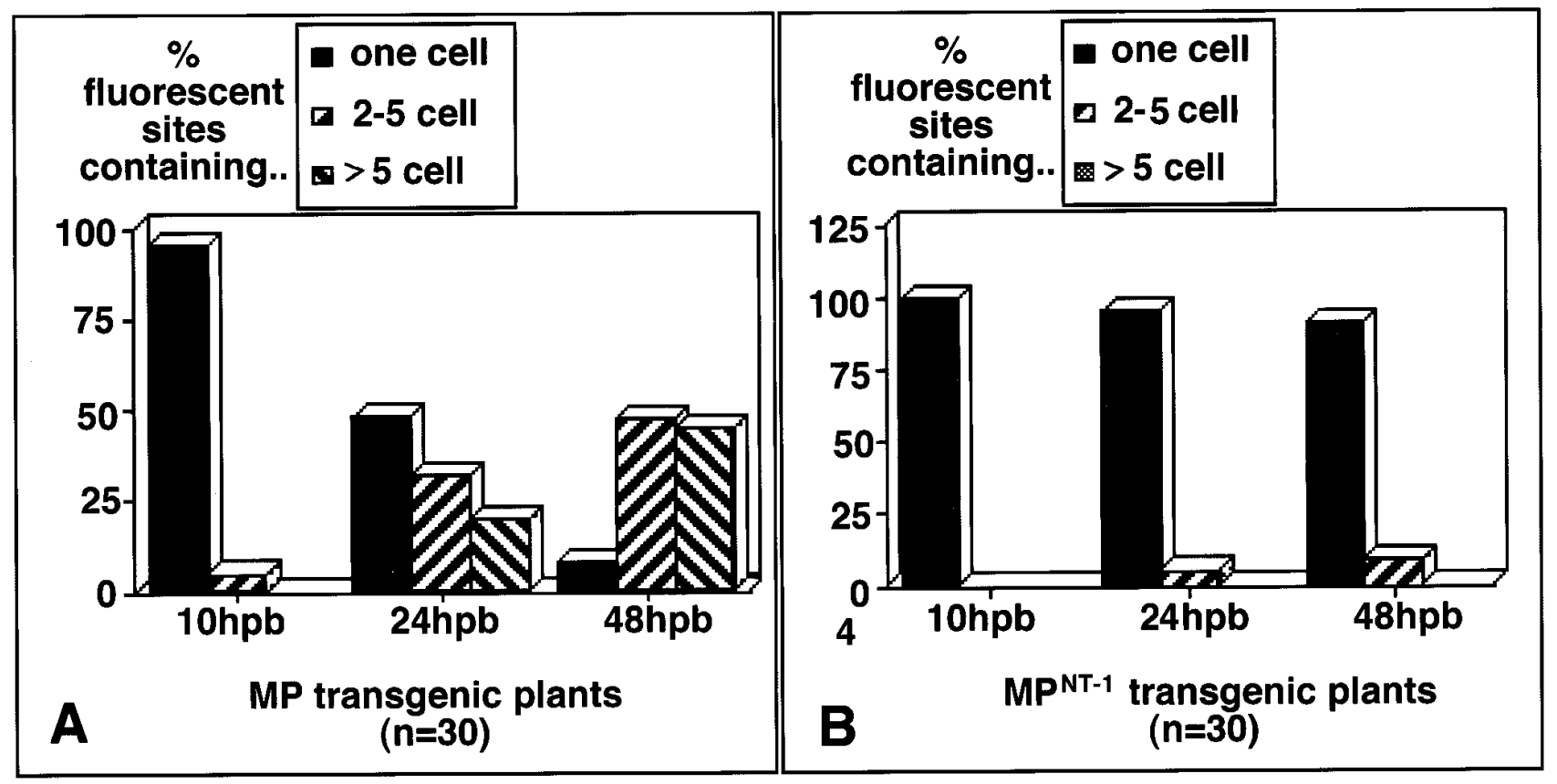

Fig. 2. Graphic representation showing the extent of the cell-to-cell spread of Tobacco mosaic virus movement protein fused to green florescent protein $\left(\mathrm{MP}^{\mathrm{TMV}}\right.$ :GFP) between epidermal cells in source leaves of $\mathbf{A}$, wild-type Nicotiana benthamiana and $\mathbf{B}$, transgenic $N$. benthamiana expressing MP ${ }^{\mathrm{NT}-1}$. Extent of the spread was determined at 10, 24, and $48 \mathrm{~h}$ following bombardment of the leaf with $p 35 S$ - $m p: g f p$. 
late in Pd. This localization pattern persists to $48 \mathrm{hpb}$ (Fig. $5 \mathrm{~B}$ ), after which the fluorescent signal begins to dissipate.

\section{Transient expression of MP ${ }^{\mathrm{TMV}}$ :GFP in transgenic $N$. benthamiana expressing MP ${ }^{\mathrm{NT}-1}$.}

When wild-type TMV is inoculated to transgenic plants expressing the MP $\mathrm{MT}^{\mathrm{NT}-1}$ mutant, the rate of local spread of infection is reduced (Cooper et al. 1995; Lapidot et al.1993). To test whether the reduction in local spread is the result of a competition between $\mathrm{MP}^{\mathrm{NT}-1}$ and MP for binding sites in the cell, we examined the targeting pathway of transiently expressed $\mathrm{MP}^{\mathrm{TMV}}$ :GFP in leaves of transgenic $N$. benthamiana plants that contain $\mathrm{MP}^{\mathrm{NT}-1}$. At 6 to $8 \mathrm{hpb}$, some of the $\mathrm{MP}^{\mathrm{TMV}}$ :GFP was in fluorescent bodies similar to those seen on nontransgenic plants but without any detectable accumulation on the cell cytoskeleton. The number of fluorescent aggregates per cell, however, was lower than in nontransgenic plants (Fig. 6). This pattern was observed in over $90 \%$ of the 33 cells examined. Furthermore, at 6 to $8 \mathrm{hpb}, \mathrm{MP}^{\mathrm{TMV}}$ :GFP already could be detected in some sites that localized to sites close to the cell wall and transwall structures (presumptive Pd) (Fig.
6B). At $24 \mathrm{hpb}, \mathrm{MP}^{\mathrm{TMV}}$ :GFP was localized to transwall structures (presumptive $\mathrm{Pd}$ ), in more than $50 \%$ of the cells. Unlike what occurs in nontransgenic plants, however, cell-to-cell movement was observed only for $3 \%$ of the cells. In cells in which $\mathrm{MP}^{\mathrm{TMV}}$ :GFP was not localized to $\mathrm{Pd}$, the protein was associated with cortical bodies and, in these cells, no cell-tocell movement was observed. At $48 \mathrm{hpb}$, although $\mathrm{MP}^{\mathrm{TMV}}$ :GFP localized to the transwall structures (presumptive $\mathrm{Pd}$ ), in all cells observed, its movement to adjacent cells was detected only in approximately $10 \%$ of the cells (Fig. 2B). It thus appears that $\mathrm{MP}^{\mathrm{NT}-1}$ interferes with the association of $\mathrm{MP}^{\mathrm{TMV}}$ :GFP with MT and reduces the efficient trafficking of MP through Pd. Targeting to the Pd, however, is not reduced.

\section{Expression of MP ${ }^{\mathrm{NT}-1}$ :GFP by infection} of BY-2 protoplasts with a recombinant virus.

Previously, it was shown that the time course of $\mathrm{MP}^{\mathrm{TMV}}$ :GFP targeting to host components in infection sites in leaves and protoplasts is similar (Heinlein et al. 1998; Reichel and Beachy 1998). To determine whether the subcellular targeting profile of $\mathrm{MP}^{\mathrm{NT}-1}$ :GFP differs between virus-infected
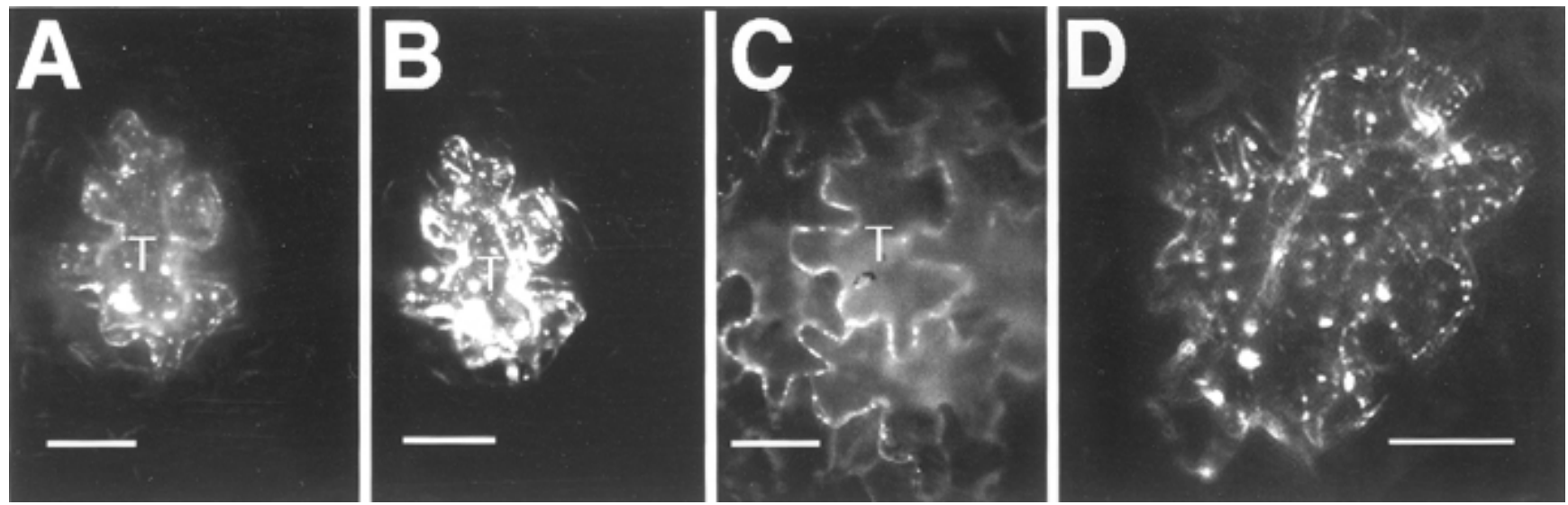

Fig. 3. Fluorescence micrograph of epidermal cells of Nicotiana benthamiana source leaf showing $\mathrm{MP}^{\mathrm{TMV}}$ :GFP targeting and cell-to-cell movement. Micrographs photographed 6 (A and D), 12 (B), and 24 (C) h postbombardment of leaves with p35S-mp:gfp. A-C, Time series of a single site over $24 \mathrm{~h}$ (T identifies cell transfected with plasmid DNA and followed over $24 \mathrm{~h}$ ). D, Independent cell photographed at higher magnification. Bar $=10 \mu \mathrm{m}$.
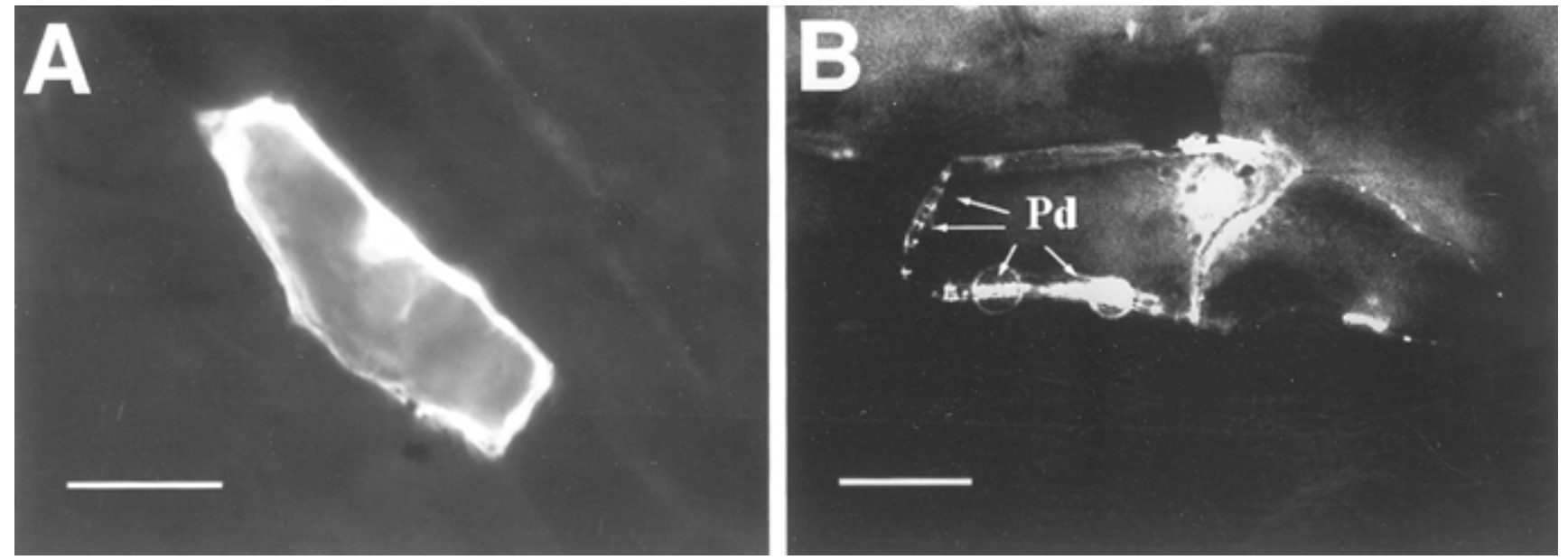

Fig. 4. Fluorescence micrograph showing expression of $\mathbf{A}$, free green fluorescent protein (GFP) and $\mathbf{B}, \mathrm{MP}^{\mathrm{TMV}}$ :GFP in epidermal source cells of bifoliate cowpea leaf $48 \mathrm{~h}$ postbombardment. Arrows indicate punctate fluorescent transwall structures, presumed to arise from MP ${ }^{\mathrm{TMV}}$ :GFP targeting to plasmodesmata. Bar $=10 \mu \mathrm{m}$. 
and viral-free transiently expressing cells, a recombinant virus encoding $\mathrm{MP}^{\mathrm{NT}-1}$ :GFP was constructed (TMV-MP ${ }^{\mathrm{NT}-1}$ :GFP) and used to infect BY-2 protoplasts. Protoplasts infected either with TMV-MP ${ }^{\mathrm{NT}-1}$ :GFP or TMV-MP ${ }^{\mathrm{TMV}}:$ GFP were harvested and fixed at 10, 20, 30, and $48 \mathrm{~h}$ postinoculation (hpi). In accordance with previous studies, in protoplasts infected with TMV-MP ${ }^{\mathrm{TMV}}$ :GFP, fluorescent bodies of increasing size were observed at 10 and at 20 hpi (Fig. 7A and B). At 10 and 20 hpi, filaments were only weakly detectable, but by $30 \mathrm{hpi}$, fluorescence accumulated on filaments and there was a decrease in the number of fluorescent bodies (Fig. 7C). The majority of fluorescence had disappeared at 48 hpi (Fig. 7D).

In protoplasts infected with TMV-MP ${ }^{\mathrm{NT}-1}$ :GFP contained much less fluorescence associated with cytoplasmic bodies than did protoplasts infected with TMV-MP ${ }^{\mathrm{TMV}}$ :GFP (compare Fig. 7A with $\mathrm{E}$ and $\mathrm{B}$ with $\mathrm{F}$ ). During the early stages of TMV-MP ${ }^{\mathrm{NT}-1}$ :GFP infection (Fig. 7E), most fluorescence was concentrated in filaments, which became even more fluorescent during the course of infection (Fig. 7F to $\mathrm{H}$ ). Moreover, unlike protoplasts infected with TMV-MP ${ }^{\mathrm{TMV}}$ :GFP, filaments were still visible at $48 \mathrm{hpi}$. Therefore, MT association of $\mathrm{MP}^{\mathrm{NT}-1}$ :GFP was much more enhanced and persistent than that of $\mathrm{MP}^{\mathrm{TMV}}$ :GFP. These observations confirm the observations in plant cells transiently expressing $\mathrm{MP}^{\mathrm{NT}-1}$ GFP (described above).

\section{Expression of MP ${ }^{\mathrm{NT}-1}$ :GFP by infection of MP transgenic plants with recombinant virus.}

To examine the subcellular accumulation of $\mathrm{MP}^{\mathrm{NT}-1}$ :GFP during plant infection, $N$. benthamiana transgenic plants that contain wild-type MP were infected with TMV-MP ${ }^{\mathrm{NT}-1}$ :GFP. In control experiments, transgenic plants were infected with TMV-MP ${ }^{\text {TMV }}$ :GFP. Infection sites caused by TMV$\mathrm{MP}^{\mathrm{TMV}}$ :GFP form radially expanding fluorescent rings (Fig. 8A) (Heinlein et al. 1995; Heinlein et al. 1998). In contrast, infection sites caused by TMV-MP ${ }^{\mathrm{NT}-1}$ :GFP formed expanding disks (Fig. 8F). The subcellular distribution of $\mathrm{MP}^{\mathrm{TMV}}$ :GFP and $\mathrm{MP}^{\mathrm{NT}-1}$ :GFP was analyzed in individual cells within infection sites caused by each virus. The distribution of $\mathrm{MP}^{\mathrm{TMV}}$ :GFP in infection sites of TMV-MP ${ }^{\mathrm{TMV}}$ :GFP on leaves of MP-transgenic plants was essentially the same as reported for nontransgenic plants (Heinlein et al. 1998). At the leading edge of infection, MP ${ }^{\mathrm{TMV}}$ :GFP accumulated in bands within the wall (presumably Pd) (Fig. 8B), and in small fluorescent bodies (Fig. 8C). Behind the leading edge of infection in additional interior cells of the infection ring, these bodies continued to enlarge (not shown). In cells at the trailing edge of the ring, three to five cells behind the infection front, the bodies became interlinked by filaments (Fig. 8E). Punctate fluores-
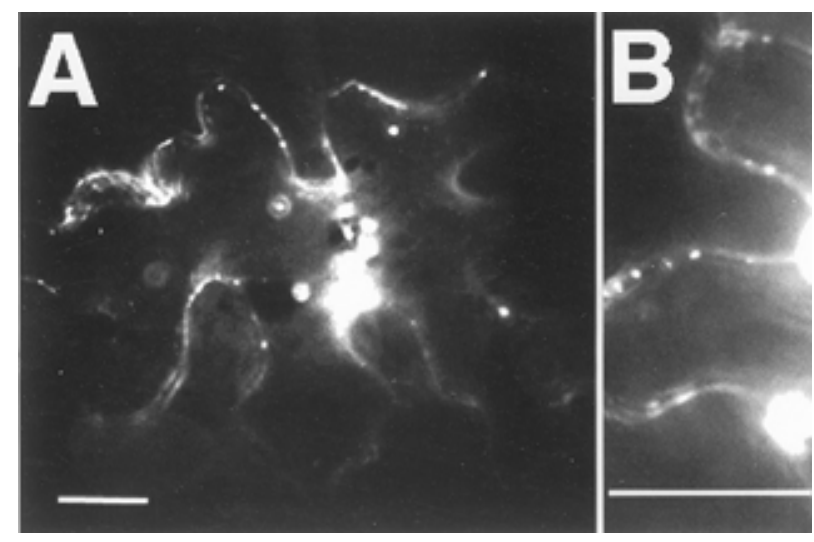

Fig. 6. Fluorescence micrograph showing expression of $\mathrm{MP}^{\mathrm{TMV}}: \mathrm{GFP}$ in epidermal cells of source leaves of transgenic Nicotiana benthamiana expressing $\mathrm{MP}^{\mathrm{NT}-1}$. At $6-8 \mathrm{~h}$ postbombardment, transiently expressed $\mathrm{MP}^{\mathrm{TMV}}$ :GFP targets in the epidermal cells of $\mathrm{MP}^{\mathrm{NT}-1}$ transgenic plants to plasmodesmata (A and B) and aggregate bodies (A). There was no association of MP ${ }^{\mathrm{TMV}}:$ GFP with cytoskeleton detected. Bar $=5 \mu \mathrm{m}$.
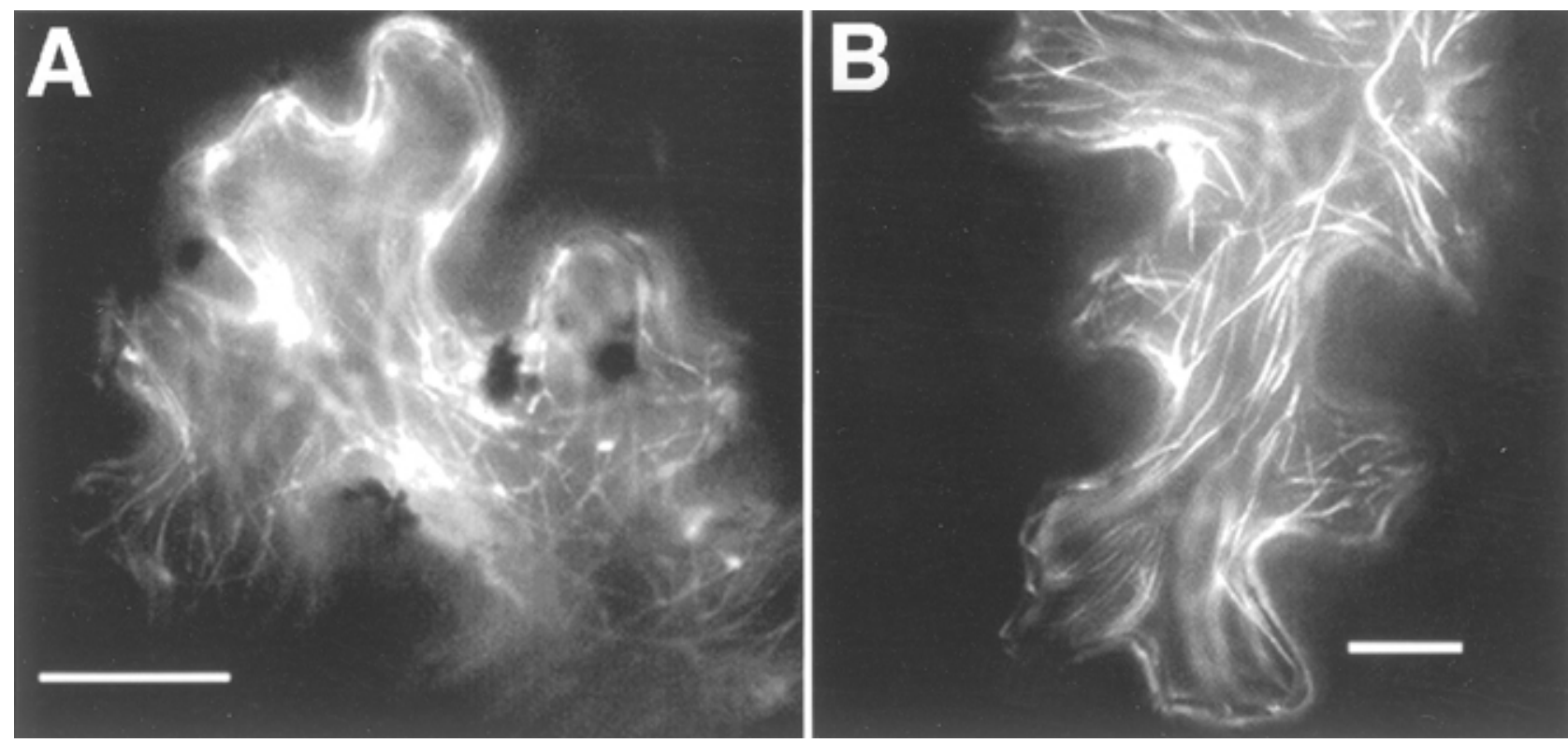

Fig. 5. Fluorescence micrograph showing expression fused to green fluorescent protein $\left(\mathrm{MP}^{\mathrm{NT}-1} \mathrm{GFP}\right)$ in epidermal cells of Nicotiana benthamiana source leaf 10 (A) and 48 (B) h postbombardment (hpb). At $10 \mathrm{hpb}, \mathrm{MP}^{\mathrm{NT}-1}$ :GFP accumulates on small aggregate bodies and the cytoskeleton (A). By 48 $\mathrm{hpb}, \mathrm{MP}^{\mathrm{NT}-1}$ GFP was still associated with cytoskeleton $(\mathbf{B})$, did not support cell-to-cell movement and could not be detected in association with plasmodesmata. $\mathrm{Bar}=10 \mu \mathrm{m}$. 
cence was associated with the wall (presumably Pd) throughout the infection site, in cell walls at the infection front (Fig. 8B1), and within the center of the ring (Fig. 8B2). In infection sites caused by the recombinant mutant virus TMV$\mathrm{MP}^{\mathrm{NT}-1}$ :GFP on transgenic plants that contain wild-type MP, there was no detectable fluorescence in $\mathrm{Pd}$, which is in agreement with the observations in nontransgenic plant cells transiently expressing $\mathrm{MP}^{\mathrm{NT}-1}$ :GFP. In cells at the leading edge of infection, $\mathrm{MP}^{\mathrm{NT}-1}$ :GFP accumulated in small fluorescent bodies (compare Fig. 8G with B1). Moreover, during the midstages of infection on transgenic plants containing wild-type $\mathrm{MP}$, the fluorescent bodies produced by TMV-MP ${ }^{\mathrm{NT}-1}$ :GFP were larger than those produced by TMV-MP ${ }^{\mathrm{TMV}}$ :GFP (compare Fig. $8 \mathrm{H}$ with $\mathrm{C}$ ). Despite the absence of $\mathrm{MP}^{\mathrm{NT}-1}$ :GFP in $\mathrm{Pd}$, however, we observed paired fluorescent bodies across the cell wall of adjacent cells (Fig. 8I), similar to those observed in infection sites caused by TMV-MP ${ }^{\mathrm{TMV}}$ :GFP (Fig. 8D). In the inner region of the infection site formed by TMV-MP ${ }^{\mathrm{NT}-}$ ${ }^{1}$ :GFP, fluorescent filamentous structures were rare and aberrant (Fig. 8J), whereas in infection sites caused by TMV$\mathrm{MP}^{\mathrm{TMV}}$ :GFP, abundant filaments were observed (Fig. 8E). Because $\mathrm{MP}^{\mathrm{NT}-1}$ :GFP interacts predominantly with filaments and, to a much lesser extent, with bodies in nontransgenic protoplasts and nontransgenic leaf cells, these results indicate that the MP expressed in transgenic plants interferes with the association of $\mathrm{MP}^{\mathrm{NT}-1}$ :GFP with MT. Additionally, because transiently expressed $\mathrm{MP}^{\mathrm{TMV}}$ :GFP does not associate with MT in $\mathrm{MP}^{\mathrm{NT}-1}$ transgenic plants, the interference between $\mathrm{MP}^{\mathrm{NT}-1}$ and MP in MT association appears to be mutual.

\section{DISCUSSION}

In the present study, we employed several approaches to gain insight into the mechanisms involved in viral spread and plant susceptibility to virus cell-to-cell spread. Because the cell-to-cell spread of TMV is MP dependent, susceptibility may require compatible interactions of MP with host factors. The proper function of MP also may require the involvement of other viral factors or host products induced by other viral factors.

In the present study, we show that the pathway of intracellular targeting of $\mathrm{MP}^{\mathrm{TMV}}$ and the propensity of $\mathrm{MP}^{\mathrm{TMV}}$ to move cell to cell are autonomous of other viral factors. In the absence of TMV infection, the intracellular localization pattern of transiently expressed MP ${ }^{\mathrm{TMV}}$ :GFP exhibited a pattern of subcellular targeting similar to that described for $\mathrm{MP}^{\mathrm{TMV}}$ :GFP in TMV-infected tissues (Epel et al. 1996; Heinlein et al. 1995; Heinlein et al. 1998; Padgett et al.1996; Reichel and Beachy 1998; this study).

Itaya et al. (1997) reported on the autonomous movement of the Cucumber mosaic virus (CMV) 3a-movement protein $3 \mathrm{aMP}{ }^{\mathrm{CMV}}$ employing $3 \mathrm{aMP}^{\mathrm{CMV}}$ :GFP. They did not, however, describe the dynamics of the intracelluar and intercellular targeting pathway. Reichel and Beachy (1998) reported that at 15 to $18 \mathrm{hpb}, \mathrm{MP}^{\mathrm{TMV}}$ :GFP accumulated in particulate structures, presumably ER and MT, and entered Pd, although they did not report the spread of $\mathrm{MP}^{\mathrm{TMV}}$ :GFP into surrounding cells. Huang and Zhang (1999) reported on the dynamics of the intracelluar and intercellular targeting pathway in onion epidermal cells of the transiently expressed MP:GFP of $\mathrm{Al}$ falfa mosaic virus.

We found that upon movement to adjacent cells, $\mathrm{MP}^{\mathrm{TMV}}$ :GFP was detected only in transwall structures, presumably $\mathrm{Pd}$, and that it apparently did not accumulate in the cytoplasm. Lack of accumulation in the bodies and/or MT may occur because fluorescence cannot be detected or targeting to cytoplasmic sites does not occur in these cells. The
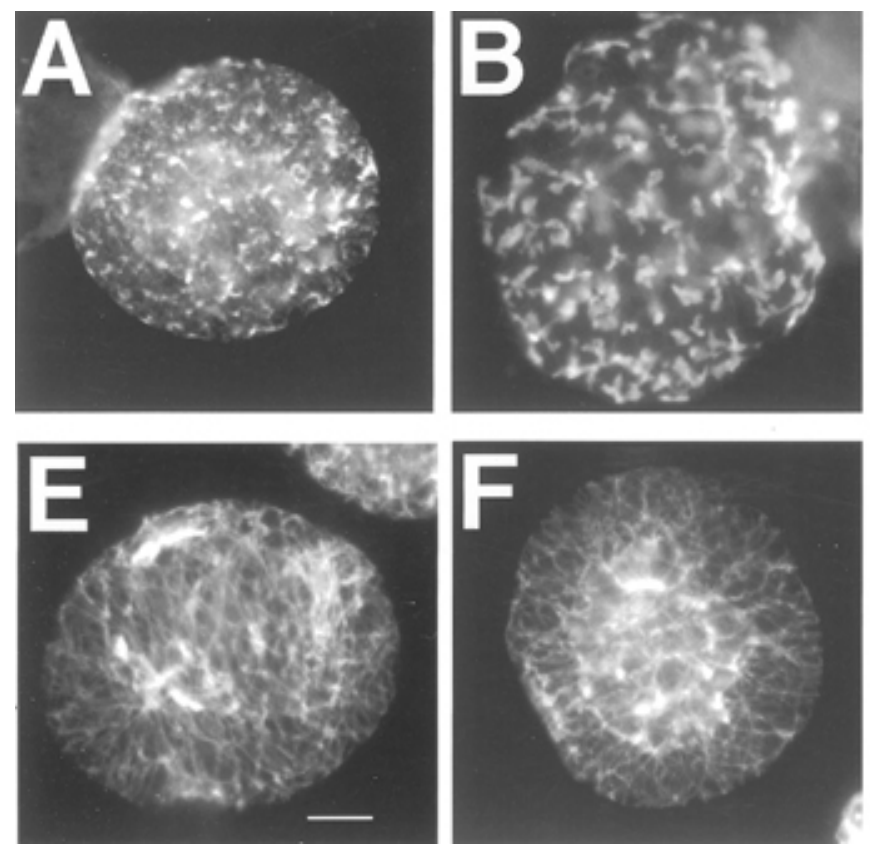
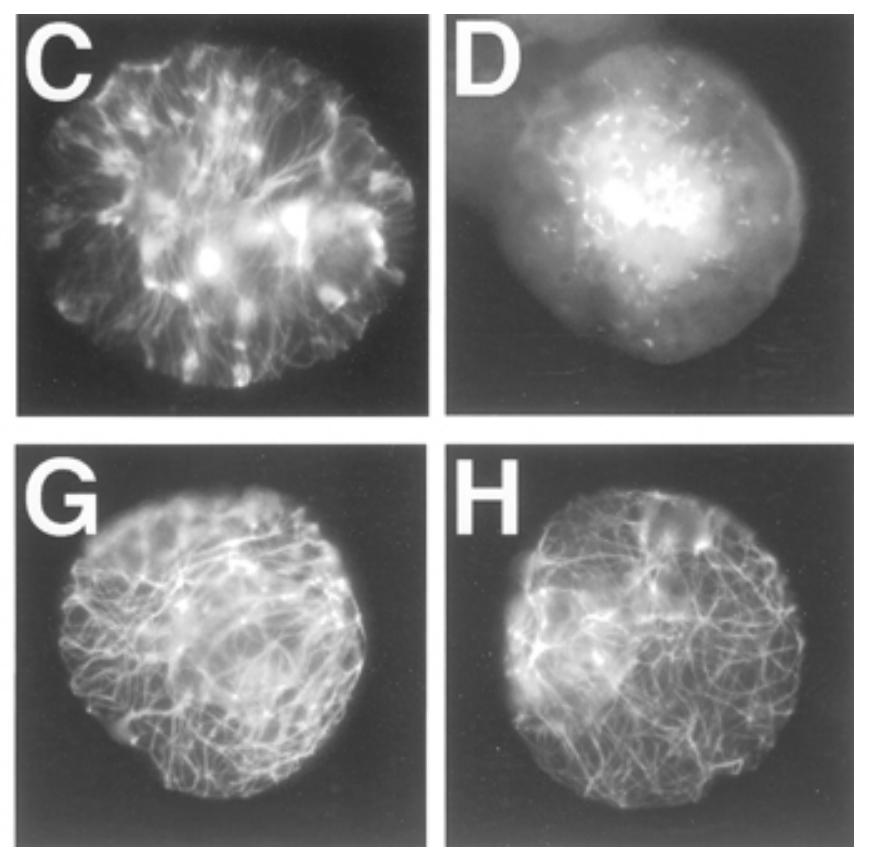

Fig. 7. Fluorescence micrographs comparing intracellular accumulation patterns of MP ${ }^{\mathrm{TMV}}: \mathrm{GFP}$ and $\mathrm{MP}^{\mathrm{NT}-1}$ :GFP in $\mathrm{BY}-2$ protoplasts infected with $\mathbf{A}-$ D, TMV- MP ${ }^{\mathrm{TMV}}$ :GFP or E-H, TMV-MP ${ }^{\mathrm{NT}-1}$ :GFP at 10 (A and E), 20 (B and F), 30 (C and G), and $48 \mathrm{~h}(\mathbf{D}$ and $\mathbf{H})$ postinoculation (hpi). MP ${ }^{\mathrm{TMV}}$ :GFP at $10(\mathbf{A})$ and $20(\mathbf{B})$ hpi accumulates in inclusion bodies, whereas MP $\mathrm{PT}^{\mathrm{NT}-1}$ :GFP shows a decreased tendency to accumulate in bodies (E and F), instead showing association with microtubules as early as $10 \mathrm{hpi}(\mathbf{E})$. C, MP ${ }^{\mathrm{TMV}}: \mathrm{GFP}$ associates with microtubules. D, By 48 hpi, the MP ${ }^{\mathrm{TMV}}: \mathrm{GFP}$ association with microtubule is no longer detectable. In contrast, at $20(\mathbf{F}), 30(\mathbf{G})$, and 40 hpi $(\mathbf{H}), \mathrm{MP}^{\mathrm{NT}-1}$ :GFP remains associated with microtubules. Bar $=10 \mu \mathrm{m}$. 
changing pattern of subcellular targeting of $\mathrm{MP}^{\mathrm{TMV}}$ :GFP in the target cell may indicate that either MP-induced changes in host proteins and/or posttranslational modifications of MP potentiate the capacity of MP to move within and between cells. We suggest that such modifications result in MP disengagement from the early sites and its targeting to Pd. The modified MP ${ }^{\mathrm{TMV}}$ :GFP is incapable of targeting to ER and is rapidly targeted to Pd in the secondary cells. It has been demonstrated that MP is phosphorylated at Ser 37 and, when Ser 37 is mutated to Ala 37, the movement function is lost and the MP does not target to the peripheral punctate bodies or to Pd (Kawakami et al. 1999). It also is possible that modifications of a host component are involved in the targeting mechanism (Mas and Beachy 1999).

When plants are infected with TMV expressing MP ${ }^{\mathrm{TMV}}$ :GFP, targeting $\mathrm{MP}^{\mathrm{TMV}}$ :GFP to $\mathrm{Pd}$ is an early event (Padgett et al. 1996) and MP ${ }^{\mathrm{TMV}}$ :GFP is detected in Pd in cells at the infection front (Heinlein et al. 1998; Oparka et al. 1997; this study). This targeting of $\mathrm{MP}^{\mathrm{TMV}}$ :GFP to Pd occurred before $\mathrm{MP}^{\mathrm{TMV}}$ :GFP accumulated in aggregates of ER and then associated with MT. In light of the present data, we suggest that the location of $\mathrm{MP}^{\mathrm{TMV}}$ :GFP in Pd at the infection front may represent MP that was synthesized in more interior cells that spread to adjacent cells, thus preparing the way for an efficient cell-to-cell spread of infection. Infectious RNA may be transported into these cells, resulting in the synthesis of a new viral replicase, MP, and coat protein (Mas and Beachy 1999). The newly synthesized MP in these cells reiterates the process. How and where MP interacts with the virus RNA to transport it to and through the Pd is an additional dimension that requires experiments with viruses. Mas and Beachy (1999) suggested that such interactions occur during virus replication.

The autonomous nature of $\mathrm{MP}^{\mathrm{TMV}}$ :GFP targeting and cellto-cell movement found in compatible hosts was used to ex- amine the nature of the incompatibility between TMV and two subliminal hosts, cowpea and cotton, as well as the restrictive nonsystemic host cucumber. In cucumber, MP ${ }^{\mathrm{TMV}}$ :GFP localized to transwall structures (presumptive Pd) and moved cell to cell, similar to what occurs in $N$. benthamiana. Thus, the inability of TMV to systematically infect cucumber is apparently unrelated to the targeting of MP to Pd. In cowpea, a subliminal host, $\mathrm{MP}^{\mathrm{TMV}}$ :GFP showed limited Pd localization and very limited cell-to-cell spread. In cotton, also a subliminal host, no localization to cortical bodies, cytoskeleton, or Pd was detectable. The lack of targeting to subcellular sites such as those in host plants suggests that in this nonhost, either the mechanism to modify the MP to allow functional targeting is lacking, a key host protein is absent, or a defense mechanism prevents MP function or results in its elimination (Reichel and Beachy 2000).

Further insights into the mechanisms of MP function were provided in studies with MP ${ }^{\mathrm{NT}-1}$. This mutant MP, which contains a 3 amino acid deletion in the $\mathrm{N}$ terminus (amino acids 3 to 5) of the protein, does not support cell-to-cell spread of infection (Gafny et al. 1992; Lapidot et al. 1993). In transgenic plants that express the mutant MP, the increase in the size exclusion limit (SEL) of the Pd was not as large as with plants expressing wild-type MP (Lapidot et al. 1993). Immunolocalization studies showed that $\mathrm{MP}^{\mathrm{NT}-1}$ did not accumulate in Pd (Lapidot et al. 1993).

In the present study, we present evidence that the presence of MP ${ }^{\mathrm{NT}-1}$ blocks an essential step in the intracellular targeting of wild-type MP ${ }^{\mathrm{TMV}}$. MP ${ }^{\mathrm{NT}-1}$ :GFP, when expressed transiently in epidermal cells of $N$. benthamiana, accumulates stably on the cytoskeleton but does not target to Pd. We suggest that the stable accumulation of $\mathrm{MP}^{\mathrm{NT}-1}$ :GFP on elements of the cytoskeleton results from a blockage in the subsequent targeting steps of $\mathrm{MP}^{\mathrm{NT}-1}$ :GFP and that such a blockage prevents its
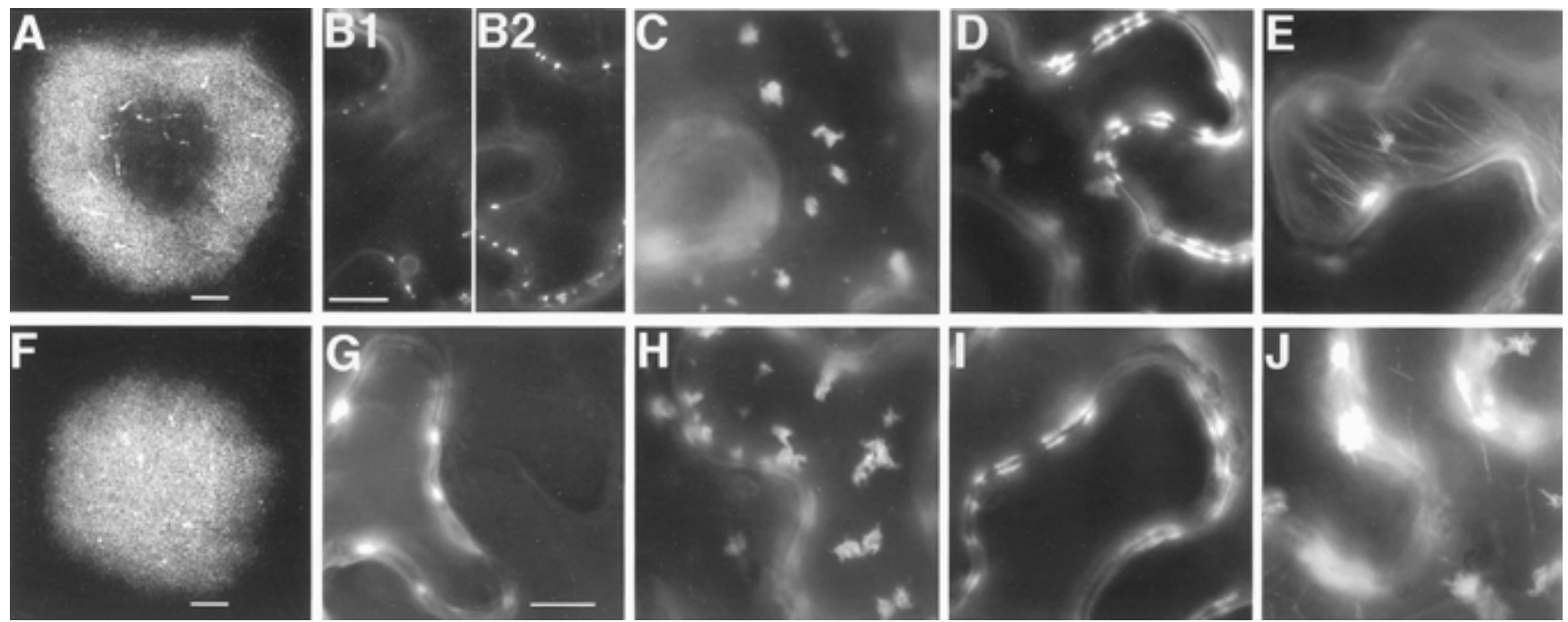

Fig. 8. Fluorescence micrographs of infection sites caused by Tobacco mosaic virus (TMV) expressing A-E, MP ${ }^{\mathrm{TMV}}$ :GFP and $\mathbf{F}-\mathbf{J}$, MP ${ }^{\mathrm{NT}-1}$ :GFP at 5 d postinoculation in leaves of Nicotiana benthamiana transgenic for wild-type MP. Infection sites caused by TMV-MP ${ }^{\mathrm{TMV}}$ :GFP form expanding rings (A), whereas sites caused by TMV-MP ${ }^{\mathrm{NT}-1}$ :GFP form expanding disks $(\mathbf{F})$. MP ${ }^{\mathrm{TMV}}$ :GFP targets to plasmodesmata (Pd) at the infection front (B1), throughout the infection site (not shown), and in the center of the fluorescent ring (B2). MP ${ }^{\mathrm{NT}-1}$ :GFP in cells at the infection front accumulates in bodies but is absent from Pd at all stages of infection $(\mathbf{G})$. Fluorescent bodies produced by MP $\mathrm{MT}^{\mathrm{NT}-1}$ :GFP at leading edge of infection $(\mathbf{H})$ are larger than bodies produced by $\mathrm{MP}^{\mathrm{TMV}}$ : GFP $(\mathbf{C})$. MP ${ }^{\mathrm{TMV}}$ :GFP and MP ${ }^{\mathrm{NT}-1}$ :GFP target to paired bodies across cell walls of adjacent cells three to five cells behind the infection front (D and I). MP ${ }^{\mathrm{TMV}}$ :GFP becomes associated with filaments close to the trailing edge of the ring (E), whereas MP ${ }^{\mathrm{NT}-1}$ :GFP filaments are rare and aberrant $(\mathbf{J})$. Bars $=0.5 \mathrm{~mm}(\mathbf{A}$ and $\mathbf{F}), 10 \mu \mathrm{m}(\mathbf{B}$ and $\mathbf{G})$, and apply to micrographs $\mathbf{B}-\mathbf{E}$ and $\mathbf{G}-\mathbf{J}$. 
accumulation in Pd and its cell-to-cell spread. In BY-2 protoplasts infected with TMV-MP ${ }^{\mathrm{NT}-1}$ :GFP, $\mathrm{MP}^{\mathrm{NT}-1}$ :GFP accumulated similarly on cytoskeletal elements. The accumulation pattern of the NT-1 mutant is very similar to the accumulation of the TAD 1 mutant MP, from which amino acids 9 to 11 were deleted (Kahn et al. 1998). These data suggest that the $\mathrm{N}$ terminus of the MP may function as a signaling domain to target the MP to Pd.

The reason for the increased stability of the cytoskeletalbound $\mathrm{MP}^{\mathrm{NT}-1}$ :GFP is unclear. It may be that $\mathrm{MP}^{\mathrm{NT}-1}$ :GFP is not posttranslationally modified, thus preventing it from being targeted for degradation (Reichel and Beachy 2000). Alternatively, it may be that $\mathrm{MP}^{\mathrm{NT}-1}$ :GFP is bound strongly to the cytoskeletal components and moves at low rates to sites for degradation or that only after further progression in the intracellular targeting program can the MP be modified to potentiate its targeting either to Pd or the degradation pathway.

When transgenic plants that produce $\mathrm{MP}^{\mathrm{NT}-1}$ were subjected to biolistic bombardment with the p35S-mp:gfp plasmid, the localization of $\mathrm{MP}^{\mathrm{TMV}}$ :GFP and rate and scope of cell-to-cell movement of the protein were affected. In these studies, we observed reduced numbers of large ER aggregates typical of the $\mathrm{MP}^{\mathrm{TMV}}$ :GFP expression in wild-type plants. Furthermore, localization to $\mathrm{Pd}$, which generally occurred only at later stages, was seen as early as $8 \mathrm{hpb}$. Movement to adjacent cells was limited, however, and at $48 \mathrm{hpb}$, only $10 \%$ of the sites showed cell-to-cell movement.

When transgenic plants expressing $\mathrm{MP}^{\mathrm{TMV}}$ were infected with the recombinant virus $\mathrm{TMV}-\mathrm{MP}^{\mathrm{NT}-1}$ :GFP, the pattern of accumulation of $\mathrm{MP}^{\mathrm{NT}-1}$ :GFP was altered in that $\mathrm{MP}^{\mathrm{NT}-1}$ :GFP failed to accumulate on MT and instead accumulated in large stable fluorescent aggregate bodies. The stable accumulation of $\mathrm{MP}^{\mathrm{NT}-1}$ :GFP in large fluorescent bodies gave rise to the disk-like appearance of the expanding infection site. It thus appears that the presence of the transgenic MP interferes with the movement of $\mathrm{MP}^{\mathrm{NT}-1}$ :GFP from the aggregate bodies to $\mathrm{MT}$, just as $\mathrm{MP}^{\mathrm{NT}-1}$ interfered with the association of $\mathrm{MP}^{\mathrm{TMV}}$ with MT.

These results provide an explanation as to why the spread of TMV infection is reduced on NT-1 expressing transgenic plants. We show that although the MP ${ }^{\mathrm{NT}-1}$ mutant is capable of performing some of the functions of the MP ${ }^{\mathrm{TMV}}$ :GFP, it becomes blocked in the intracellular targeting program, accumulates on MT, and is unable to target to Pd. Virus movement function is thus abolished. Moreover, because $\mathrm{MP}^{\mathrm{NT}-1}$ shares some degree of localization with $\mathrm{MP}^{\mathrm{TMV}}$ :GFP, the presence of $\mathrm{MP}^{\mathrm{NT}-1}$ interferes with the normal program that targets intracellular accumulation of MP ${ }^{\mathrm{TMV}}$. We suggest that the NT-1 mutant, when coexpressed in planta with wild-type MP, competes with the wild-type MP for host component(s) essential for virus movement, thus slowing cell-to-cell spread.

Because limited SEL changes were observed in transgenic plants expressing $\mathrm{MP}^{\mathrm{NT}-1}$ (Lapidot et al. 1993), and $\mathrm{MP}^{\mathrm{NT}-1}$ interferes with the movement function of wild-type MP but does not interfere with $\mathrm{MP}^{\mathrm{TMV}}$ targeting to $\mathrm{Pd}$, we suggest that in planta MP undergoes a complex series of interactions with host membranes, cytoskeletal elements, host proteins, and viral RNA, each of which is essential for the maturation of a movement-competent protein. One also must consider the hypothesis that MP causes changes in Pd SEL, not through direct interaction with the $\mathrm{Pd}$, but indirectly by affecting a host function that gates the Pd. Such a possibility is supported by the observations that i) $\mathrm{MP}^{\mathrm{NT}-1}$ partially alters Pd SEL without targeting to the Pd (Lapidot et al. 1993), ii) Pd SEL is altered during the sink-to-source transition in leaves (Oparka et al. 1999), iii) changes in ATP levels alter Pd SEL (Cleland et al. 1994 ; Tucker 1993), and iv) Pd conductivity is sensitive to pressure gradients (Oparka and Prior 1992) and $\mathrm{Ca} 2+$ (Holdaway-Clarke et al. 2000). The mechanisms involved in altering Pd SEL remain unclear.

\section{MATERIALS AND METHODS}

\section{Constructs and plants.}

$N$. benthamiana, $N$. tabacum cv. Xanthi, C. sativa, and cotton (Gossypium hirsutum L.) plants were grown under greenhouse conditions for 4 to 6 weeks. Cowpea (Vigna unguiculata) was grown for approximately 4 weeks under fluorescent lighting (14 h light-10 h dark). Transgenic $N$. benthamiana line NB15 (Giesman-Cookmeyer et al. 1995) expressing wildtype MP was a gift from M. Deom (University of Georgia). Transgenic $N$. benthamiana line NB105, which expresses the mutant MP that lacks amino acids 3, 4, and $5\left(\mathrm{MP}^{\mathrm{NT}-1}\right)$ in the $\mathrm{N}$ terminus, were regenerated via Agrobacterium spp.mediated leaf-disk transformation (Horsch et al. 1985). Biolistic tissue transformation was performed with $N$. benthamiana source leaves and cucumber or cotton cotyledons from plants at a four-leaf stage or with fully expanded bifoliate cowpea leaves.

\section{Molecular cloning.}

Plasmid $p 35 S-m p: g f p$ contains a CaMV promoter (Jefferson et al. 1987) and the MP ${ }^{\mathrm{TMV}}$ coding sequence minus the nine residues at it $\mathrm{C}$ terminus, as previously described (Heinlein et al. 1995), fused to a GFP analog in which Ser 65 was mutated to tyrosine, a mutation that enhances fluorescence by 20 -fold (Heim et al. 1995). To express the $\mathrm{MP}^{\mathrm{TMV}}$ :GFP fusion, a transient expression vector based on pBI221 (Clontech, Palo Alto, California, U.S.A.) was constructed. To ligate the $\mathrm{MP}^{\mathrm{TMV}}$ :GFP sequence to the plasmid, the pBI221 plasmid was modified to include a XhoI site to accommodate the prospective insert. The beta glucuronidase gene was excised from pBI221 with use of the BamHI and NotI sites and a ubiquitin-like sequence used in unrelated experiments was inserted. Later the ubiquitin sequence was excised with the BamHI site and a XhoI site near the 3' end of the ubiquitin coding sequence.

An $\mathrm{MP}^{\mathrm{TMV}}$ :GFP fusion product was amplified by polymerase chain reaction (PCR) from a TMV vector containing the $\mathrm{MP}^{\mathrm{TMV}}$ :GFP fusion spaced by a read-through linker (Heinlein et al. 1995; Padgett et al 1996) with a forward primer containing a BamHI site (GAGGATCCATGGCTCTAGTTG) and the GFP-R primer containing a XhoI site (5'GAATCTCGAGTTAGACTAGTTCATCCATGC). The PCR product was isolated and digested with $\mathrm{BamHI}$ and $\mathrm{XhoI}$ and ligated into the modified $\mathrm{pBI} 221$ vector.

The expression plasmid p35S-nt-1:gfp contains a 35S $\mathrm{CaMV}$ promoter and the coding sequence of the mutant TMV movement protein, $\mathrm{MP}^{\mathrm{NT}-1}$, fused translationally to GFP. The coding sequence for $\mathrm{MP}^{\mathrm{NT}-1}$ was introduced via PCR amplification of the MP ${ }^{\mathrm{TMV}}$ :GFP template used above with use of a $5^{\prime}$ primer that encodes the first eight amino acids of the mutant plus a BamH1 site (GCGGATCCATGGCTAAAGGAAAA- 
GTGAATATC) and the $3^{\prime}$ GFP reverse primer containing a XhoI site downstream of a stop codon (5'-GAATCTCGAGTTAGACTAGTTCATCCATGC). The ATG start codon was introduced as part of the $5^{\prime}$ primer sequence.

All cloning techniques, ligations, digestions, and gel separations were performed as described in Sambrook et al. (1992). Plasmid preps were performed with the Qiagen plasmid minicolumn kit (Valencia, CA, U.S.A.). PCR was performed as described previously (Sambrook et al 1992) with an MJ Research PCR minicycler (Waltham, MA, U.S.A.) and an ExTaq proofreading Taq polymerase (Takara Shuzo, Mie, Japan). The PCR program used was $94^{\circ} \mathrm{C}$ for 3 min followed by 32 cycles of $94^{\circ} \mathrm{C}$ for $1 \mathrm{~min}$; annealing temperature of 45 to $60^{\circ} \mathrm{C}$, depending upon the primer composition, for $1 \mathrm{~min}$; and elongation temperature of $72^{\circ} \mathrm{C}$ for $2 \mathrm{~min}$. Following 32 cycles, a final step of $72^{\circ} \mathrm{C}$ for 5 min was employed. The reaction conditions were Ex-Taq buffer with $2.5 \mathrm{mM} \mathrm{MgCl} 2,0.2 \mathrm{mM}$ each dNTP, 25 pmoles of each primer, and $1 \mathrm{U}$ of the enzyme in a $50-\mu$ reaction volume. PCR products were gel purified with the Geneclean kit (Qbiogene, Montreal, Canada).

\section{Biolistic tissue transfection.}

Biolistic tissue transformation was performed essentially as described by Sanford et al. (1992). Briefly, $1 \mu \mathrm{g}$ of plasmid DNA was combined with $10 \mu \mathrm{l}$ of 1.2-micron prepared tungsten particles (0.45 mg tungsten, M1; Bio-Rad, Hercules, CA, U.S.A.), $10 \mu \mathrm{l}$ of $1 \mathrm{M} \mathrm{CaCl}_{2}$, and $4 \mu \mathrm{l}$ of $0.1 \mathrm{M}$ spermidine (Sigma) in a microcentrifuge tube. The mixture was vortexed for $3 \mathrm{~min}$, and the particles were allowed to stand for $1 \mathrm{~min}$. Particles were collected by centrifugation and washed once in $70 \%$ ethanol, followed by a wash in $100 \%$ ethanol. The coated tungsten particles were dried on a macrocarrier membrane (Bio-Rad) and introduced to the abaxial side of the leaf with a PDS-1000/He pneumatic particle gun (Bio-Rad) with an 1,100-psi rupture disk (Bio-Rad). Bombardment was performed under the following conditions: vacuum of 28 -in. $\mathrm{Hg}$, helium pressure of $1,100 \mathrm{psi}$, and target distance of $10 \mathrm{~cm}$. Following bombardment, leaf tissue was incubated in the dark in petri dishes for up to $72 \mathrm{~h}$. After incubation, samples were mounted on slides in $0.4 \mathrm{M}$ mannitol and $0.1 \%$ Tween-20.

\section{Inoculation of plants and protoplasts.}

$N$. benthamiana plants were inoculated mechanically with the recombinant virus TMV-MP:GFP5 or TMV-MP ${ }^{\text {NT- }}$ ${ }^{1}$ :GFP5 by rubbing the leaves (in the presence of carborundum) with transcripts derived from in vitro reactions with pT5-nx2 and pTf5:N5 (Van der Laak and Heinlein, unpublished) as templates. TMV-MP:GFP5 encoded by pT5-nx2 is identical to TMV-MP:GFP encoded by the pTMV-M:GfusBr used previously (Heinlein et al. 1995; Heinlein et al. 1998; Oparka et al. 1997), except that the MP coding sequence is fused translationally to an improved version of GFP (mGFP5) (Siemering 1996). Moreover, unique-flanking NruI and XhoI restriction sites were introduced and used to exchange the MP:GFP5 open reading frame for $\mathrm{MP}^{\mathrm{NT} 1}$ :GFP5, resulting in pTf5:N5. The mutation in MP $\mathrm{MP}^{\mathrm{NT}-1}$ (a deletion of amino acids 3 to 5) was created by in vitro PCR mutagenesis with the subcloned BamH1-KpnI fragment of pT5-nx2 as template. All plasmids were verified by sequencing. The virus-inoculated plants were maintained at $22^{\circ} \mathrm{C}$ during the 16 -h photoperiod and at $20^{\circ} \mathrm{C}$ during the dark period.
Protoplasts of tobacco suspension cell line BY-2 were prepared and inoculated by electroporation with infectious transcripts, as described (Watanabe et al. 1987). Following inoculation, protoplasts were resuspended in $10 \mathrm{ml}$ of medium, and $1-\mathrm{ml}$ aliquots in 35-mm petri dishes were cultured in the dark at $28^{\circ} \mathrm{C}$. Actinomycin D $(30 \mu \mathrm{g}$ per $\mathrm{ml})$, which increases MP accumulation (Blum et al. 1989), was added to the protoplasts from a stock solution prepared with dimethyl sulfoxide as solvent.

\section{Fluorescent microscopy.}

Fluorescence microscopy generally was performed with a DMBRE microscope (Leica Microsystems, Wetzlar, Germany) with a 50-W mercury lamp and equipped with a L4 filter cube (excitation filter of 450 to $490 \mathrm{~nm}$, dichromatic mirror RKP 510, and suppression filter BP515 to 560). Images were recorded with a Photometrics Sensys CCD camera (KAF0400; Roper Scientific, Ottobrunn, Germany), and processed with PMIS software, version 3.5 (EHD Imaging, Damme, Germany).

Alternatively, in experiments with BY-2 protoplasts and leaf viral infections, fluorescence microscopy was performed with an Eclipse E800 microscope equipped with CFI Plan Apochromat objectives (Nikon, Tokyo, Japan). A XF100 filter set (Omega Optical, Brattleboro, VT, U.S.A.) was used to visualize GFP fluorescence. Whole fluorescent infection sites on leaves were viewed with 2 or $4 \times$ lenses. Leaf disks placed on glass slides were used for high-magnification microscopy with $100 \times$ oil-immersion objectives. Protoplasts were analyzed with 60 and $100 \times$ oil-immersion lenses. Images were acquired and processed with an ORCA-100 progressive scan interline CCD camera (Hamamatsu Photonics, Hamamatsu City, Japan) and Openlab 2 software (Improvision, Coventry, England). Images were prepared for publication with Adobe Photoshop software (Adobe Systems, Mountain View, CA, U.S.A.).

\section{ACKNOWLEDGMENTS}

We are grateful to A. Zelcer and D. Wolf (Department of Genetics, Volcani Center, Israel) for transformation of $N$. benthamiana plants with the $\mathrm{MP}^{\mathrm{NT}-1}$ mutant. This research was supported in part by research grants IS-2636-95 from BARD, the United States-Israel Binational Agricultural Research and Development Fund (BLE), and 891-0141-98 from DIARP, the Dutch-Israeli Agricultural Research Program (BLE).

\section{LITERATURE CITED}

Atabekov, J. G., and Taliansky, M. E. 1990. Expression of a plant viruscoded transport function by different viral genomes. Adv. Virus Res. 38:201-248.

Atkins, D., Hull, R., Wells, B., Roberts, K., Moore, P., and Beachy, R. N. 1991. The tobacco mosaic virus 30k movement protein in transgenic tobacco is localized to plasmodesmata. J. Gen. Virol. 72:209-211.

Blum, H., Gross, H. J., and Beier, H. 1989. The expression of the TMVspecific $30-\mathrm{kDa}$ protein in tobacco protoplasts is strongly and selectively enhanced by actinomycin. Virology 169:51-61.

Boyko, V., Ferralli, J., Ashby J., Schellenbaum P., and Heinlein M. 2000a. Function of microtubules in intercellular transport of plant virus RNA. Nat. Cell Biol. 2:826-832.

Boyko V., Van Der Laak, J., Ferralli, J., Suslova, E., Kwon, M. O., and Heinlein, M. 2000b. Cellular targets of functional and dysfunctional mutants of Tobacco mosaic virus movement protein fused to green fluorescent protein. J. Virol. 74:11339-11346.

Cleland, R. E., Fujiwara, T., and Lucas, W. J. 1994. Plasmodesmatal- 
mediated cell-to-cell transport in wheat roots is modulated by anaerobic stress. Protoplasma 178:81-85.

Cooper, B., Lapidot, M., Heick, J. A., Dodds, J. A., and Beachy, R. N. 1995. A defective movement protein of TMV in transgenic plants confers resistance to multiple viruses whereas the functional analog increases susceptibility. Virology 206:307-313.

Deom, C. M., Oliver, M. J., and Beachy, R. N. 1987. The 30-kilodalton gene product of tobacco mosaic virus potentiates virus movement. Science 237:389-394.

Ding, B., Haudenshield, J. S., Hull, R. J., Wolf, S., Beachy, R. N., and Lucas, W. J. 1992. Secondary plasmodesmata are specific sites of localization of tobacco mosaic virus movement in transgenic tobacco plants. Plant Cell 4:915-928.

Epel, B. L., Padgett, H. S., Heinlein, M., and Beachy, R. N. 1996. Plant virus movement protein dynamics probed with a movement protein fused to the GFP. Gene 173:75-79.

Gafny, R., Lapidot, M., Berna, A., Holt, C. A., Deom, C. M., and Beachy, R. N. 1992. Effects of terminal deletion mutations on function of the MP of tobacco mosaic virus. Virology 187:499-507.

Giesman-Cookmeyer, D., Silver, S., Vaewhongs, A. A., Lommel, S. A., and Deom, C. M. 1995. Tobamovirus and dianthovirus movement proteins are functionally homologous. Virology 213:38-45.

Heim, R., Cubitt, A. B., and Tsien, R. Y. 1995. Improved green fluorescence. Nature 373:663-664.

Heinlein, M., Epel, B. L., Padgett, H. S., and Beachy, R. N. 1995. Interaction of tobamovirus movement proteins with the plant cytoskeleton. Science 270:1983-1985.

Heinlein, M., Padgett, H. S., Gens, J. S., Pickard, B. G., Casper, S. J., Epel, B. L., and Beachy, R. N. 1998. Changing patterns of localization of the tobacco mosaic virus movement protein and replicase to the endoplasmic reticulum and microtubules during infection. Plant Cell 10:1107-1120.

Holdaway-Clarke, T. L., Walker, N. A., Hepler, P. K., and Overall, R. L. 2000. Physiological elevations in cytoplasmic free calcium by cold or ion injection result in transient closure of higher plant plasmodesmata. Planta 210:329-335.

Horsch, R. B., Fry, J. E., Hoffmann, N. L., Eichuoltz, D., Rogers, S. G., and Fraley, R. T. 1985. A simple and general method for transforming genes into plants. Science 227:1229-1231.

Huang, M., and Zhang, L. 1999. Association of the movement protein of alfalfa mosaic virus with the endoplasmic reticulum and its trafficking in epidermal cells of onion bulb scales. Mol. Plant-Microbe Interact. 12:680-690.

Hull, R. 1989. The movement of viruses in plants. Annu. Rev. Phytopathol. 27:213-240.

Jefferson, R. A., Kavanagh, T. A., and Beven M. W. 1987. GUS fusion: $\beta$-Glucuronidase as a sensitive and versatile gene fusion marker in higher plants. EMBO J. 8:3901-3907.

Itaya, A., Hickman, H., Bao, V., Nelson, R., and Ding, B. 1997. Cell-tocell trafficking of cucumber mosaic virus movement protein: Green fluorescent protein fusion produced by biolistic gene bombardment in tobacco. Plant J. 12:1223-1230.

Kahn, T. W., Lapidot, M., Gafny, R., Heinlein, M., Reichel, C., and Beachy, R. N. 1998. Sequence domains of the TMV movement protein involved in subcellular localization. Plant J. 15:15-25.

Kawakami, S., Padgett, H. S., Hosokawa, D., Okada, Y., Beachy, R. N., and Watanabe, Y. 1999. Phosphorylation and/or presence of serine 37 in the movement protein of tomato mosaic tobamovirus is essential for intracellular localization and stability in vivo. J. Virol. 73:68316840.

Lapidot, M., Gafny, R., Ding, B., Wolf, S., Lucas, W. J., and Beachy, R. N. 1993. A dysfunctional movement protein of tobacco mosaic virus that partially modifies the plasmodesmata and limits virus spread in transgenic plants. Plant J. 4:959-970.

Lazarowitz, S., and Beachy, R.N. 1999. Viral movement proteins as probes for intracellular and intercellular trafficking in plants. Plant Cell 11:535-548.

Mas, P., and Beachy, R. N. 1999. Replication of tobacco mosaic virus on endoplasmic reticulum and role of the cytoskeleton and virus movement protein in intracellular distribution of viral RNA. J. Cell Biol. 147:945-958.

McLean, B. G., Zupan, J., and Zambryski, P. C. 1995. Tobacco mosaic virus movement protein associates with the cytoskeleton in tobacco cells. Plant Cell 7:2101-2114.

Meshi, T., Watanabe, Y., Saito, T., Sugimoto, A., Maeda, T., and Okada, Y. 1987. Function of the $30 \mathrm{kd}$ protein of tobacco mosaic virus: Involvement in cell-to-cell movement and dispensability for replication. EMBO J. 6:2557-2563.

Moore, P. J., Fenczik, C. A., and Beachy, R. N. 1992. Developmental changes in $\mathrm{PD}$ in transgenic tobacco expressing the movement protein of tobacco mosaic virus. Protoplasma 170:115-127.

Oparka, K. J., and Prior, D. A. M. 1992. Direct evidence for pressuregenerated closure of plasmodesmata. Plant J. 2:741-750.

Oparka, K. J., Prior, D. A., Santa Cruz, S., Padgett, H. S., and Beachy, R. N. 1997. Gating of epidermal plasmodesmata is restricted to the leading edge of expanding infection sites of tobacco mosaic virus (TMV). Plant J. 12:781-789.

Oparka, K. J., Roberts, A. G., Boevink, P., Santa Cruz, S., Roberts, I., Pradel, K. S., Imlau, A., Kotlizky, G., Sauer, N., and Epel, B. 1999. Simple, but not branched, plasmodesmata allow the nonspecific trafficking of proteins in developing tobacco leaves. Cell 97:743-754.

Padgett, H. S., Epel, B. L., Kahn, T. W., Heinlein, M., Watanabe, Y., and Beachy, R. N. 1996. Distribution of tobamovirus movement protein in infected cells and implications for cell-to-cell spread of infection. Plant J. 10:1079-1088.

Reichel, C., and Beachy, R. N. 1998. Tobacco mosaic virus infection induces severe morphological changes of the endoplasmic reticulum. Proc. Natl. Acad. Sci. USA 15:11169-11174.

Reichel, C., and Beachy, R. N. 2000. Degradation of tobacco mosaic virus movement protein by the $26 \mathrm{~S}$ proteosome. J. Virol. 74:33303337.

Sambrook, J., Fritsch, E. F., and Maniatis, T. 1989. Molecular Cloning: A Laboratory Manual. Cold Spring Harbor Laboratory, Cold Spring Harbor, NY, U.S.A.

Sanford, J. C., Smith, F. D., and Russell, J. A. 1993. Optimizing the biolistic process for different biological applications. Methods Enzymol. 217:483-509.

Siemering, K. R., Golbik, R., Sever, R., and Haseloff, J. 1996. Mutations that suppress the thermosensitivity of green fluorescent protein. Curr. Biol. 6:1653-1663.

Sulzinski, M. A., and Zaitlin, M 1982. Tobacco mosaic virus replication in resistant and susceptible plants: In some resistant species virus is confined to a small number of initially infected cells. Virology 121:12-19.

Szécsi, J., Ding, X. S., Lim, C. O., Bendahmane, M., Cho, M. J., Nelson, R. S., and Beachy, R. N. 1999. Development of tobacco mosaic virus infection sites in Nicotiana benthamiana. Mol. Plant-Microbe Interact 12:143-152.

Tucker, E. B. 1993. Azide treatment enhances cell-to-cell diffusion in staminal hairs of Setcreasea purpurea. Protoplasma 174:45-49.

Van Lent, J., Wellink, J., and Goldbach, R. 1990. Evidence for the involvement of the $58 \mathrm{~K}$ and $48 \mathrm{~K}$ proteins in the intercellular movement of cowpea mosaic virus. J. Gen. Virol. 71:219-223.

Waigmann, E., Lucas, W. J., Citovsky, V., and Zambryski, P. 1994. Direct functional assay for tobacco mosaic virus cell-to-cell movement protein and identification of a domain involved in increasing plasmodesmatal permeability. Proc. Natl. Acad. Sci. USA 91:1433-1437.

Watanabe, Y., Meshi, T., and Okada, Y. 1987. Infection of tobacco protoplasts with in vitro transcribed tobacco mosaic virus RNA using an improved electroporation method. FEBS Lett. 219:65-69. 